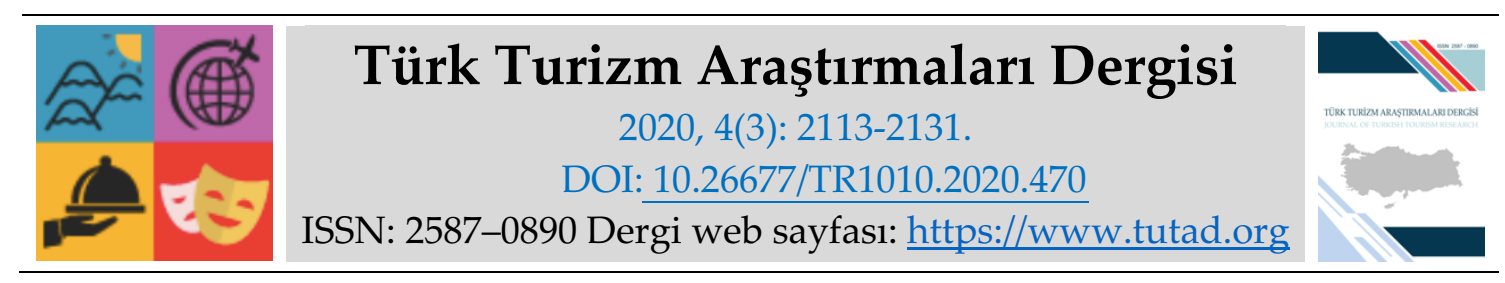

ARASTIRMA MAKALESI

\title{
Gençlerin Kış Sporlarına Katılım Kısıtlarının İncelenmesi: Gümüşhane Üniversitesi Öğrencileri Örneği
}

Dr. Öğr. Üyesi Savaş EVREN, Gümüşhane Üniversitesi, Turizm Fakültesi, Gümüşhane, e-posta: savasevren@gumushane.edu.tr

ORCID: https://orcid.org/0000-0003-4558-9720

Öz

Kış turizmi özellikle 1960'lardan itibaren hem arz hem de talep açısından hızlı bir gelişim kaydetmiştir. Ancak güncel raporlar, kış turizmi pazarının büyüme hızının son 15 yıldır yavaşladığını, insanların kış sporlarına katılma hızının düştügünü göstermektedir. Bu noktadan hareketle çalışmada, kış turizmi pazarının önemli bölümünü oluşturan gençlerin kış sporlarına katılım kısıtlarının belirlenmesi amaçlanmıştır. Bu kapsamda, Gümüşhane Üniversitesi öğrencilerine anket uygulanmış ve 457 kişiden oluşan bir örnekleme ulaşılmıştır. Elde edilen veriler; tanımlayıcı istatistikler, açımlayıcı faktör analizi, T-testi, ANOVA ve çoklu doğrusal regresyon analizleriyle incelenmiştir. Bulgulara göre, gençler için kış sporlarına katılımda en önemli kısıt, maddi yetersizliktir. Ardından sırasıyla; partner eksikliği, cazip gelmeme, korkutehlike ve sosyal kaygı gelmektedir. Farklı gelir, cinsiyet ve rekreasyonel tercih gruplarında bulunan gençler arasında çeşitli kısıtlar açısından anlamlı farklılıklar bulunmuştur. Ayrıca katılımcıların kış sporlarına yönelik ilgi düzeyleri üzerinde korku-tehlike ve cazip gelmeme faktörlerinin negatif anlamlı etkisi olduğu tespit edilmiştir.

Anahtar Kelimeler: Kış Sporları, Boş Zaman Kısıtları, Gençler, Gümüşhane.

Makale Gönderme Tarihi: 12.03 .2020

Makale Kabul Tarihi: 05.07.2020

\section{Önerilen Atıf:}

Evren, S. (2020). Gençlerin Kış Sporlarına Katılım Kısıtlarının İncelenmesi: Gümüşhane Üniversitesi Öğrencileri Örneği, Türk Turizm Araştırmaları Dergisi, 4(3): 2113-2131.

(C) 2020 Türk Turizm Araştırmaları Dergisi. 


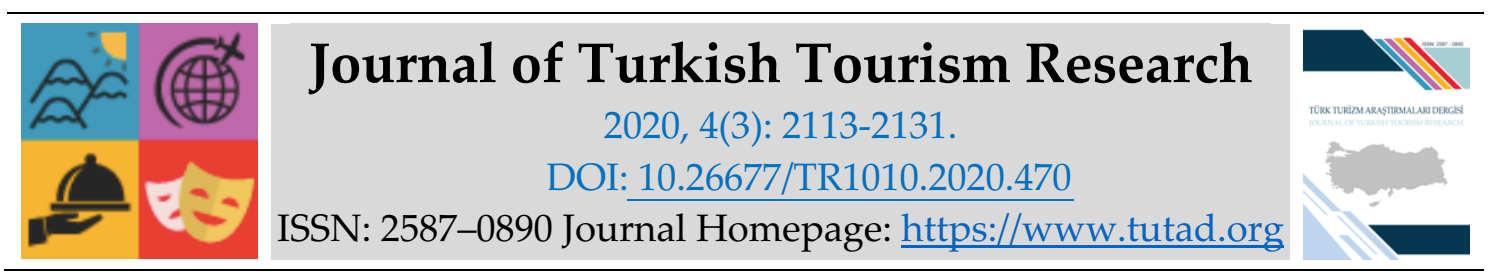

\title{
RESEARCH PAPER
}

\section{Examination of Winter Sports Participation Constraints of the Youth: The Case of Gümüşhane University Students}

Assistant Prof. Dr. Savaş EVREN, Gümüşhane University, Faculty of Tourism, Gümüşhane, email: savasevren@gumushane.edu.tr ORCID: https://orcid.org/0000-0003-4558-9720

\begin{abstract}
Winter tourism has made a rapid development in terms of both supply and demand, especially since the 1960s. The current reports reveal that there is a deceleration in the growth rate of winter tourism market in last 15 years and that participation rate of people to winter sports got slower. From this viewpoint, it is aimed to determine the winter sports participation constraints of young people who constitute the large part of the winter tourism market. In this context, a questionnaire was applied to Gümüşhane University students and a sample of 457 people was reached. The data were analyzed with descriptive statistics, exploratory factor analysis, T-test, ANOVA and multiple linear regression analysis. According to the results, most important constraint was "financial insufficiency" for the youth. Following "financial insufficiency" related constraints, "lack of partner", "finding unattractive", "fear-danger" and "social anxiety" come. Significant differences were found between people in different income, gender, and recreational preferences groups in terms of various constraints. In addition, it is found that factors of "fear-danger" and "finding unattractive" have significant negative effect on the interest levels of participants for winter sports.
\end{abstract}

Keywords: Winter Sports, Leisure Constraints, Youth, Gümüşhane.

Received: 12.03 .2020

Accepted: 05.07.2020

\section{Suggested Citation:}

Evren, S. (2020). Examination of Winter Sports Participation Constraints of the Youth: The Case of Gümüşhane University Students, Journal of Turkish Tourism Research, 4(3): 2113-2131.

(C) 2020 Türk Turizm Araştırmaları Dergisi. 


\section{GİRIŞ}

Kış sporları, ister rekreasyonel isterse profesyonel amaçlı olsun, insanların zevk alarak gerçekleştirdikleri önemli spor etkinliklerindendir. $\mathrm{Bu}$ sporun eğlence amaçlı gerçekleştirilmesiyle oluşan kış turizmi ise turizm endüstrisi içinde en fazla ekonomik getiri sağlayan alanlardan biridir. Özellikle II. Dünya Savaşından sonra küresel kış turizminde önemli gelişmeler yaşanmış; bu kapsamda destinasyon ve turist sayısı hızla artmıştır (Hudson, 2003: 8991). Ancak Laurent Vanat tarafından her yıl düzenli olarak yayımlanan Uluslararası Kar ve Dağ Turizmi Raporunda (her ne kadar akademik bir rapor olmasa da), sektörün büyüme hızının son 15 yıldır düştügüu, neredeyse stabil hale geldiği ifade edilmektedir (Vanat, 2020:16). Yazar, yakın zamana kadar, dünya genelindeki tüm kayakçıların yıl içinde kaydıkları toplam gün sayısının 2020 yılında 400 milyona ulaşacağının öngörüldüğünü, ancak bu sayının 2018-2019 yılında 350 milyon civarında kaldığını ve dolayısıyla ilgili öngörünün gerçekleşmesinin pek mümkün olmadığını belirtmektedir. 2018-2019 sezonunun oldukça iyi geçtiğini, hatta son 41 yılın en iyi dördüncü sezonu olduğunu belirten Vanat (2020:16), bu durumun sektör için olumlu olduğunu, ancak uzun dönemli bir büyümenin işareti olmadığını ifade etmektedir. Ayrıca 2018-2019 yılı itibariyle toplam kış turizmi pazar büyüklüğünün 135 milyon kişi civarında olduğunu belirten yazar, pazarın beklenen ölçüde büyümediğini ve bu noktada kayak yapma kültürünün yeterince yaygınlaşmamış olmasının ve şehir gençliğinin ilgisinin tam olarak çekilememesinin önemine dikkat çekmektedir (Vanat, 2020:219).

Pazarın büyüme hızının yavaşlaması, insanların neden eskisi kadar kış turizmine katılmadığı sorusunu akla getirmektedir. Bu kapsamda, çalışmanın problemi, insanları kış turizmine katılım noktasında nelerin kısıtladığıdır. Bu problem, literatürde seyahat kısıtları veya boş zaman kısıtları başlı̆ğ altında incelenmekte; insanların belirli turizm türlerine veya rekreasyon etkinliklerine neden katılamadıkları tartışılmaktadır. Kış sporları açısından da benzer araştırmalara, özellikle uluslararası literatürde rastlamak mümkündür (Alexandris vd., 2017; Vassiliadis vd., 2018). Ancak bu araştırmalarda genel olarak, kış sporları pazarının tamamı incelenmekte, özel olarak gençler üzerinde durulmamaktadır. Türkiye'de ise kış turizminde seyahat motivasyonu (Albayrak, 2013), iklim değişikliği (Demiroğlu, 2016), destinasyon performansı (Evren ve Kozak, 2019), hizmet kalitesi (Sağlık ve Kocaman, 2014), destinasyon algıları (Koşan, 2013), seyahat davranışı (Ayaz ve Apak, 2017) vb., konularda bazı araştırmalara rastlansa da kış sporlarına katılım kısıtlarını esas alan bir çalışmaya rastlanmamıştır.

$\mathrm{Bu}$ değerlendirmeler ışı̆̆ında, mevcut çalışmanın amacı, kış turizmi pazarının en önemli bölümlerinden birini oluşturan gençleri, kış sporlarına katılma noktasında kısıtlayan unsurların neler olduğunun belirlenmesidir. Bu çerçevede, genç nüfusun önemli bir kısmını $(\% 33,6)$ oluşturan üniversite öğrencileri hedef alınmış ve Gümüşhane Üniversitesi öğrencileri üzerinde bir araştırma gerçekleştirilmiştir1. Çalışmada aşağıdaki sorulara yanıtlar bulunarak hem literatüre hem de sektöre katkı sunulmaya çalışılmıştır.

\footnotetext{
${ }^{1}$ TÜİK' in 2018 yılı gençlik raporuna göre (en güncel rapor), Türkiye' de 15-29 yaş arasındaki genç nüfus, toplum nüfusun \%23,8'ini oluşturmaktadır. Bu noktadan hareketle, 2018 yılı nüfusunun 82.003.882 olduğu düşünüldügünnde, Türkiye' de bu yaş aralığındaki kişilerin sayısının 19.516.923 olduğu anlaşılmaktadır. YÖK ise 2018-2019 yılında üniversiteye devam eden öğrenci sayısının 7.740.502 olduğunu açıklamıştır. Bu kapsamda, genç nüfusun \%33,6'sının üniversite öğrencilerinden oluştuğu ifade edilebilir. TÜIK' in gençlik raporunda Gümüşhane nüfusunun \%28,4'ünün 15-29 yaş aralığında olduğu ifade edilmektedir. Bu oran, 2018 yılındaki 162.748 kişilik il nüfusu içinde 46.086 kişinin genç kategorisinde değerlendirilebileceğini göstermektedir. Gümüşhane Üniversitesinin aynı yıl içindeki öğrenci sayısı ise 17.102'dir ve dolayısıyla
} 
S1. Kış sporlarına katılım kısıtları ölçeğinin nasıl bir faktör yapısı vardır?

S2. Hangi kısıtlar, gençleri kış sporlarına katılım konusunda daha fazla etkilemektedir?

S3. Farklı demografik özelliklere sahip gençler arasında, kış sporları kısıtlarına ilişkin algılar açısından farklılıklar var mıdır?

S4. Gençlerin kış sporlarına yönelik genel ilgi düzeyi nasıldır?

S5. Gençlerin kış sporlarına yönelik ilgileri/ilgisizlikleri üzerinde hangi kısıt faktörlerinin etkisi vardır?

\section{KAVRAMSAL ÇERÇEVE}

Kısıtlar konusu, turizm ve boş zaman literatüründe uzun zamandır üzerinde durulan bir konudur. İlk kez 1960'ların başlarında konuşulmaya başlanan bu konu (Hung ve Petrick, 2012:857), 1980'lerde teorik olarak tartışılmaya ve yaygın olarak incelenmeye başlamıştır (Hudson vd., 2010:72). Bu kapsamda, öncelikle boş zaman kısıtları alanındaki çalışmalar yaygınlaşmaya başlamış, ardından bu çalışmaların ortaya koyduğu teorik çerçeveyi temel alan seyahat kısıtları literatürü gelişmeye başlamıştır (Nyaupane ve Andereck, 2008; Hung ve Petrick, 2012:857).

"İnsanların boş zaman aktivitelerine katılımını, hizmetlerden yararlanmasını ve halihazırda katıldıkları etkinliklerden aldıkları tatmin ve eğlence duygusunu sınırlandıran faktörler" şeklinde tanımlanan (Scott, 2003:75) boş zaman kısıtları konusundaki tartışmaların önemli bir bölümü, ilgili kısıtların neler olduğu ve insanları nasıl kısıtladıklarıyla ilgilidir. Bu kapsamda, üzerinde en fazla durulan teori, Crawford ve Godbey'in $(1987,1991)$ Hiyerarşik Boş Zaman Kısıtları Teorisi'dir. Bu teoriye göre; insanların boş zaman etkinliklerine katılımını kısıtlayan üç temel faktör vardır; kişisel kısıtlar, kişilerarası kısıtlar ve yapısal kısıtlar. Birey hiyerarşik olarak öncelikle kişisel kısıtların etkisi altında kalmakta, bu kısıtları aştığında karşısına kişilerarası kısıtlar çıkmaktadır. Son aşamada ise birey, yapısal kısıtlarla karşı karşıya kalmaktadır. Kişisel kısıtlar, bireyin içsel durumunun yansıması olarak ortaya çıkan stres, korku, tutumlar ve beceriler gibi kısıtları ifade ederken; kişilerarası kısıtlar, arkadaşlar ve aile gibi yakın çevreden kaynaklanan kısıtlardır. Örneğin bireyin bir etkinliği yapmaktan korkması kişisel bir kısıt iken; ailesinin ona yüklediği sorumluluklar (çocuk bakımı vb.) veya arkadaşlarının bu etkinliğe ilgi duymaması, para ayırmak istememesi vb. kısıtlar kişilerarası kısıtlar kapsamında değerlendirilmektedir. Yapısal kısıtlar ise bireyin etkinliğe ayıracak zamanının ve/veya parasının olmaması, etkinliğin erişilebilirliğinin düşük olması, etkinlik alanının kalabalık ve uzak olması, etkinliğe ilişkin bilgi eksikliği gibi etkenleri içermektedir (Gilbert ve Hudson, 2000; Walker ve Virden, 2005).

Bazı araştırmacılar hiyerarşik kısıtlar teorisinin boş zaman kısıtlarını açıklamadaki etkisini kabul etmekle birlikte, alternatif sınıflandırmalar ortaya koymaktadırlar. Örneğin Gürbüz ve Karaküçük (2007) gerçekleştirdikleri ölçek geliştirme araştırmasında, boş zaman kısıtlarını sekiz başlık altında sınıflandırmışlardır: tesis, ulaşım, kentsel koşullar, arkadaş eksikliği, bilgi eksikliği, para, sosyal çevre ve zaman. Öte yandan, Alexandris vd., (2017) boş zaman kısıtlarının "maliyet", "zaman", "psikolojik", "partner" ve "çevre" şeklinde beş boyutlu olarak ele alınabileceğini

Gümüşhane'nin genç nüfusunun \%37,1'inin üniversite öğrencilerinden oluştuğu söylenebilir (TUIKK, 2020a, 2020b; YÖK, 2020; Gümüşhane Üniversitesi, 2020). Bu çerçevede, gerek Türkiye genelinde gerekse Gümüşhane'de, üniversiteli gençlerin önemli bir orana sahip olduğu anlaşılmaktadır. 
belirtmektedir. Bazı araştırmacılar ise boş zaman kısıtlarının anlaşılmasında, yukarıda değinilen etkenlere ek olarak; kültür, motivasyon, engelle mücadele gibi değişkenlerin önemine dikkat çekmektedirler (Hubbard ve Mannell, 2001; Hudson vd., 2010). Örneğin, Hudson vd.'ne (2010) göre kültür; bireyin kişisel, kişilerarası ve yapısal kısıtları algılaması, etkinliğe ilişkin motivasyonu ve rekreasyonel etkinlik tercihleri üzerinde etkisi olan önemli bir değişkendir.

Literatürde, sınıflandırması nasıl olursa olsun bazı kısıtların, çoğu rekreasyon ve turizm etkinliğinde öne çıtığ görülmektedir. Bu kapsamda, özellikle maddi kısıtların insanları katılmak istedikleri etkinliklerde büyük ölçüde sınırlandırdığı ve gelir değişkeninin çoğu insanı istedikleri etkinliklere katılma noktasında kısıtlayıcı bir unsur olduğu anlaşılmaktadır (Michailidis vd., 2006; Williams ve Fidgeon, 2000). Bunun dışında; yaş, sağlık durumu, cinsiyet, kültürel uyum gibi değişkenlerin de rekreasyonel etkinliklere katılım üzerinde etkisi olduğu kimi çalışmalarla ortaya konmaktadır (Williams ve Lattey, 1994; Alexandris ve Carrol, 1997; Chick vd., 2018).

\section{İLGİLI ARAŞTIRMALAR}

Kış sporlarına katılım kısıtları gerek bir rekreasyonel etkinlik olarak gerekse bir turizm faaliyeti olarak, son 20 yıldır literatürün üzerinde durduğu bir konudur. Bu kapsamda, önemli bir kısmı Yunanistan kaynaklı olan (Michailidis vd., 2006; Andronikidis vd., 2007; Alexandris vd., 2008 Priporas vd., 2015; Vassiliadis vd., 2018) bazı araştırmalara rastlamak mümkündür (Gilbert ve Hudson, 2000; Williams ve Fridgeon, 2000; Fredman ve Heberlein, 2005; Hudson vd., 2010; Chick vd., 2018). Bu araştırmaların bazılarında sadece henüz kayakçı/ziyaretçi olmayanlar üzerinde durulurken (Williams ve Fridgeon, 2000; Michailidis vd., 2006); bazılarında mevcut ve potansiyel kayakçılar karşılaştırılmıştır (Gilbert ve Hudson, 2000; Fredman ve Heberlein, 2005). Bazı araştırmalarda ise herhangi bir ayrım yapılmadan, genel olarak kış turizmi pazarının algıları çerçevesinde kısıtlar değerlendirilmiştir (Andronikidis vd., 2007; Vassiliadis vd., 2018).

Yukarıda değinilen araştırmalar genel olarak incelendiğinde; henüz kayak sporuna başlamamış insanları, bu etkinliğe katılma noktasında kısıtlayan en önemli kısıtların maliyet ve fiziksel zorluk olduğu görülmektedir. Örneğin, Williams ve Fridgeon (2000), Kanada'da kayakçı olmayanlar üzerinde gerçekleştirdikleri anket çalışmasında, bu kişilerin kayağı yüksek düzeyde fiziksel zorluk içeren, pahalı bir spor olarak algıladıklarını ve en çok ekipman ve ulaşım maliyetleri ile fiziksel zorluklar tarafından kısıtlandıklarını tespit etmişlerdir. Benzer şekilde, Michailidis vd., (2006) tarafından Yunanistan'da yürütülen çalışmada, kış sporlarını öğrenme zorluğu ve ekipman maliyetleri, en etkili kısıtlar olarak bulunmuştur. Kayakçılar ve henüz kayakçı olmayanları karşılaştıran çalışmalarda ise yapısal kısıtlar (Fredman ve Heberlein, 2005) ve kişisel kısıtların (Gilbert ve Hudson, 2000) kayakçı olmayanları, kayakçılara göre daha fazla etkilediği tespit edilmiştir. Ayrıca uzaklık, gelir ve diğer ekonomik faktörlerin her iki grubu da kısıtladığ ortaya konmuştur (Gilbert ve Hudson, 2000; Fredman ve Heberlein, 2005).

Kış turizmi pazarının genel incelemesini yapan, diğer bir ifadeyle kayakçı ve kayakçı olmayan ayrımına bakmayan çalışmalarda da benzer değişkenler öne çıkmaktadır. Özellikle maddi kısıtlar (ekipman, giysi, ulaşım, bilet fiyatları) araştırmaların büyük bir kısmında katılımcıların en önemli gördüğü kısıtlar olmuştur (Andronikidis vd., 2007; Alexandris vd., 2017; Vassiliadis vd., 2018). Bazı araştırmalarda ise kısıtların herkesi aynı şekilde etkilemediği, farklı gruplar arasında kısıt algısı farklılıkları olduğu ortaya konmuştur (Hudson, 2000; Michailidis vd., 2006; Priporas vd., 2015). Örneğin Priporas vd., (2015), Yunanistan' da gerçekleştirdikleri araştırmada, katılımcıların demografik özelliklerini, kısıt algılarını ve davranışsal profillerini temel alarak kümeleme analizi yapmışlar ve beş farklı küme elde etmişlerdir. "Genel olarak kısıtlı turistler", "finansal/maddi olarak kısıtlılar", "arkadaş ve aile kısıtlıları", "az kısıtlılar" ve "kış sporlarının tadını çıkaranlar" ş̧eklinde 
adlandırılan bu beş kümenin, benzer yönleri olmakla birlikte, genel olarak farklı şekillerde kısıtlandıkları tespit edilmiştir.

Literatürde kış turizmi kısıtlarını kültürel farklıları temel alarak inceleyen çalışmalar da mevcuttur. Örneğin Hudson vd. (2010), kış turizmine katılım açısından kültürel kimliğin etkisini sorgulamışlardır. Bu kapsamda yazarlar, Çin kökenli Kanadalılar ve İngiliz kökenli Kanadalılar arasındaki farklılıklara bakmışlardır. Odak gruplar ve yarı yapılandırılmış görüşmelerle yapılan araştırmada, Çinli-Kanadalıların kişisel kısıtlardan yüksek düzeyde etkilendikleri, İngilizKanadalıların ise daha çok yapısal kısıtlarla kısıtlandıkları tespit edilmiştir. Bu bağlamda, kültürel kimliğin kış turizmine katılım kısıtları üzerinde etkisi olduğu yorumunda bulunmuşlardır. Bir diğer kültür temelli araştırmada Chick vd., (2018) boş zaman kısıtları ile boş zaman memnuniyeti arasındaki ilişkide kültürel uyumun aracı etkisini incelemiş ve bu ilişkinin anlamlı olduğunu tespit etmişlerdir.

Genel olarak değerlendirildiğinde, kış sporlarına katılım açısından, finansal kısıtlar ve öğrenme zorluğu/tehlikesine ilişkin kısıtların öne çıktığı ifade edilebilir. Bu kapsamda, özellikle ekipman, ulaşım, konaklama vb. maliyetler ile öğrenme sürecinde yaşanan düşmelere bağlı sakatlanma kaygısının önemli olduğu anlaşılmaktadır. Fakat bu faktörler, kış sporları pazarı içindeki tüm kesimleri aynı şekilde kısıtlamamaktadır. Pazarın bazı bölümleri maddi kısıtlardan daha fazla etkilenirken, bazıları tehlike/korku kısıtından, bazılarıysa bunlardan tamamen farklı kısıtlardan (başka etkinlikleri tercih etme, partner bulamama vb.) daha fazla etkilenmektedir. Bu noktada, destinasyonlar açısından önemli olan, hangi kesimin hangi kısıtlardan daha fazla etkilendiğinin belirlenmesi ve ona yönelik çözümler geliştirilmesidir.

\section{YÖNTEM}

\section{Veri Toplama Aracı}

Çalışmada veriler anket tekniğiyle toplanmıştır. Kullanılan anket üç bölümden oluşmaktadır: demografik sorular, kış sporlarına katılım kısıtları ölçeği (KSKKÖ), kış sporlarına ilgi düzeyi ölçeği. Demografik sorular kapsamında yaş, cinsiyet, gelir gibi genel soruların yanı sıra Gümüşhane' de kaç yıldır bulunulduğu, Gümüşhane' nin aktif kayak merkezi olan Zigana'nın kış sporları amacıyla ziyaret edilip edilmediği ve boş zamanlarda en çok ne yapıldığı gibi sorular yer almışırı. KSKKÖ literatürde yer alan kış turizmine katılım kısıtları konulu araştırmalardan yararlanılarak oluşturulmuştur (Gilbert ve Hudson, 2000; Williams ve Fridgeon, 2000; Fredman ve Heberlein, 2005; Michailidis vd., 2006; Andronikidis vd., 2007; Alexandris vd., 2008; Hudson vd., 2010; Priporas vd., 2015; Chick vd., 2018; Vassiliadis vd., 2018;). Bu ölçek, beşli Likert Tipi (5 tamamen katılıyorum - 1 kesinlikle katılmıyorum) bir ölçektir. Örnek ifade: "Arkadaşlarımın önünde küçük düşme kaygısı kış sporlarına katılımımı kısıtlar". Kış sporlarına ilgi düzeyi ölçeği ise beş tepki kategorisine sahip (1 hiç ilgim yok -5 son derece ilgiliyim) çoklu derecelendirme listesi tarzında, eşit aralıklı bir ölçektir.

\section{Geçerlilik ve Güvenirlik}

Çalışmada KSKKÖ'nin geçerliliğini sağlamak amacıyla; kapsam/içerik geçerliliği, yüzey geçerliliği ve yapı geçerliliği tekniklerinden yararlanılmıştır. Bu kapsamda, öncelikle ilgili literatürden maddeler derlenmiş ve 32 maddeli bir madde havuzu oluşturulmuştur. Ardından turizm alanında çalışan 10 akademisyenden; gerekli, gereksiz ve gerekli-yetersiz şeklinde üç tepki kategorili bir uzman görüşü formu aracılığıyla, ilgili maddelerin ölçek için gerekli olup olmadığı yönündeki görüşleri alınmıştır. Formda ayrıca uzmanlardan ilgili maddeler ve ölçeğin 
geneli için yorumları istenmiştir. Elde edilen uzman değerlendirmeleri Lawshe'nin (1975) içerik geçerliliği hesaplama formülüyle $\left(\mathrm{KGO}=\frac{n e-n / 2}{n / 2}\right)$ incelenmiştir. Yazara göre içerik geçerliliğ oranı; bir madde için gerekli diyen uzman sayısından toplam uzman sayısının yarısının çıarılması ve elde edilen değerin toplam uzman sayısının yarısına bölünmesiyle bulunmaktadır ve 10 kişilik uzman grubunda bu değer 0,62'den büyük olmalıdır. Bu formüle göre yapılan incelemeler ve uzmanların sözlü yönlendirmeleriyle madde sayısı 29'a düşmüş ve bazı maddelerin ifade ediliş biçimi düzeltilmiştir.

Yüzey geçerliliği kapsamında ise öncelikle bazı turizm akademisyenlerine anket formu okutulmuş, ardından Gümüşhane Üniversitesi öğrencilerinden oluşan 45 kişilik grup üzerinde pilot çalışma gerçekleştirilmiştir. Bu kapsamda, ölçek maddelerinin daha iyi okunur hale getirilmesi sağlanmış, bazı demografik sorularda da değişiklik yapılmıştır. Örneğin, "aylık kişisel geliriniz" şeklinde sorulan gelir sorusu, bazı yanlış anlamalar neticesinde "aylık harcanabilir (kira vb. giderler dışında) geliriniz" şeklinde düzeltilmiştir. Pilot çalışmada ayrıca KSKKÖ'nin güvenirlik düzeyine de bakılmış ve ölçeğin yüksek düzeyde güvenilir (Cronbach $\mathrm{Alfa}=0,855$ ) olduğu anlaşılmıştır (Kayış, 2016).

KSKKÖ’nin yapı geçerliliği kapsamında ise açımlayıcı faktör analizinden (AFA) yararlanılmıştır. AFA kapsamında dört madde binişik faktör yükleri, iki madde ise düşük ortak varyanslar ve faktör yapısıyla uyumsuzlukları nedeniyle kapsam dışı tutulmuştur. Maddelerin elenmesinin ardından beş boyutlu bir yapı elde edilmiştir. Bu beş boyutlu yapı, toplam varyansın \%57'ni açılamaktadır ve boyutlar yüksek düzeyde güvenilirdir. Ayrıca elde edilen faktör yapısı, literatürle uyumludur. AFA'ya ilişkin detaylar, bulgular kısmında verilmiştir.

Güvenirlik konusunda ise pilot çalışmada olduğu gibi ana çalışmada da KSKKÖ'nün yüksek düzeyde güvenilir (Cronbach Alfa= 0,886) olduğu görülmüştür (Kayış, 2016). Ayrıca güvenirlik analizinde, ölçekten çıkarıldığında Alfa katsayısını belirgin şekilde yükselten bir madde görülmemiştir. Ölçekten çıkarıldıklarında maddelerin alfa değerleri 0,880 ile 0,886 arasında değişmektedir.

\section{Evren ve Örneklem}

Çalışmanın genel evrenini Türkiye'deki tüm üniversite öğrencileri oluştururken, araştırma evrenini Gümüşhane Üniversitesi öğrencileri oluşturmaktadır. Verilerin toplandığı 2019 yılında Gümüşhane Üniversitesinin 18.000 civarında aktif öğrencisi bulunmaktadır. Bu kapsamda, Cochran'ın (1977) sınırsız evren temsiliyeti olduğunu ifade ettiği 384 rakamının üzerinde bir öğrenci grubuna ulaşılması hedeflenmiş; 2019 yılı Mart-Nisan aylarında toplam 468 anket toplanmıştır. Anketler üzerinde yapılan ön incelemeler neticesinde beş anketin özensiz doldurulduğu, uç değer analizleri neticesinde ise altı gözlemde uç değerler olduğu anlaşılmış ve ilgili anketler veri setinden çıkarılmıştır. Nihayetinde 457 adet kullanılabilir anket elde edilmiştir. Bu kapsamda, çalışmanın örneklemi, 457 kişiden oluşmaktadır. Örneklem olarak Gümüşhane Üniversitesi öğrencilerinin tercih edilmesinin temel nedeni, şehrin genç nüfusunun çok önemli bir bölümünü onların oluşturmasıdır. Giriş bölümünde de değinildiği gibi, Gümüşhane Üniversitesi öğrencilerinin, şehrin genç nüfusu içindeki oranı \%37,1 civarındadır.

Örneklem içinde kadınların oranı \%61,3, erkeklerin oranı \%39,7' dir. Ortalamanın (641 TL) altında harcanabilir gelire sahip olanlar örneklemin \%70,7'ini, ortalamanın üstünde geliri olanlar \%29,3'ünü oluşturmaktadır. Katılımcıların önemli bir bölümünün üniversitenin bulunduğu Karadeniz Bölgesi'nden (\%32,2) olduğu, ardından sirasiyla Akdeniz (\%16,8), Doğu Anadolu $(14,4)$, İç Anadolu (\%10,9), Marmara (\%9), Güneydoğu Anadolu $(\% 7,7)$ ve Ege $(\% 5,9)$ bölgelerinin geldiği tespit edilmiştir. Katılımcıların \%84,7'sinin, şehrin tek faal kayak merkezi olan Zigana'yı 
henüz ziyaret etmedikleri ve boş zamanlarında en çok pasif eğlence ve rahatlama aktivitelerini (müzik dinleme, TV izleme, kitap okuma, uyuma gibi) tercih ettikleri görülmüştür $(\% 49,9)$.

\section{Veri Analizi}

Analizler kapsamında öncelikle verilerin analiz için uygunluğuna bakılmıştır. Bu çerçevede uçdeğer analizi ve normal dağılım analizlerinden yararlanılmıştır. Uçdeğer analizleri, yukarıda da değinildiği üzere, altı katılımcının bazı maddelerde uç değerler yarattığını ortaya koymuştur. Bu kapsamda öncelikle bu anketler veri setinden çıkarılmıştır. Ardından normal dağılımlara bakılmış ve basıklık-çarpıklık değerleri incelenmiştir. Çarpıklık değerleri 0,114'lük hata katsayısıyla -0,442 ile $+0,906$ arasında değişirken; basıklık değerleri 0,228 hata katsayısıyla $-1,274$ ile -0,464 arasında değişmektedir. Kline (2016: 76-77) çarpıklık değerlerinin -+3 arasında; basıklık değerlerinin ise -+10 arasında olması gerektiğini belirtmektedir. Bu kapsamda, verilerin uygun aralıklarda çarpık ve basık olduğu söylenebilir. Verilerin analize uygun hale getirilmesinin ardından; araştırma sorularına yanıtlar bulmak amacıyla tanımlayıcı istatistikler, AFA, T-testi, ANOVA ve çoklu doğrusal regresyon analizlerinden yararlanılmıştır.

\section{Sinirlılıklar}

Çoğu çalışmada olduğu gibi, bu çalışmada da bazı sınırlılıklardan söz etmek mümkündür. Öncelikle çalışmada öğrenci örneklemine başvurulması ve sadece gençlerin kısıtlarının incelenmesi birer sınırlılık olarak değerlendirilebilir. Ayrıca çalışmanın Gümüşhane ile sınırlı tutulması bir sınırlılık olabilir. Ancak bu sınırlılıkları, çalışmanın amacı ve kış sporlarının yapısı doğrultusunda değerlendirmekte fayda vardır. Çalışmanın amacı rekreasyonel kış sporları pazarının kısıtlarını tespit etmektir ve bu pazar içinde gençlerin önemli bir ağırlı̆̆ söz konusudur. Bu noktada Gümüşhane, il nüfusunun önemli bir bölümünü öğrenciler oluşturduğu için değerli bir araştırma sahası olarak görülebilir. Ancak farklı örneklemlerde farklı sonuçlar elde edilebileceği de bir gerçektir.

\section{BULGULAR}

\section{Kış Sporlarına Katılım Kısıtları Ölçeği AFA Bulguları}

KSKKÖ'nin faktör yapısını sorgulayan Soru 1'e yanıt bulmak için AFA'dan yararlanılmıştır. AFA'da elde edilen KMO örneklem yeterliliği değeri $(0,882)$ ve Barlett Küresellik Testi değerleri ( $\mathrm{x} 2=4579,656, \mathrm{sd}=406, \mathrm{p}=0,000)$, verilerin AFA için uygun olduğunu göstermiştir. Ancak dört maddede binişik faktör yükleri olduğu görülmüştür. Büyüköztürk vd., (2012) bir maddenin iki farklı faktördeki yükleri arasında en az 0,10 fark olması gerektiğini ifade etmektedir. İlk aşamada en yüksek binişilik değerine sahip olan "kayak merkezlerinde kar olmamasından duyduğum kaygı" (fark=0,010) maddesi çıkarılmış ve AFA tekrarlanmıştır. Ardından tüm binişik maddeler için aynı işlem gerçekleştirilmiştir. Bu kapsamda üç madde daha ölçekten çıkarılmıştır: "kış sporlarının öğrenmenin çoğu spor çeşidini öğrenmekten daha zor olması" (fark=0,019), "uygun fiyatlı herşey dahil kayak turlarının eksikliği" (fark=0,009), "1slanmak ve üşümekten duyduğum kayg1" (fark=0,049). 
Tablo 1. KSKKÖ'nin AFA Bulguları

\begin{tabular}{|c|c|c|c|c|c|c|c|c|}
\hline KSKKÖ maddeleri & 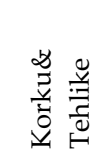 & 胥 & 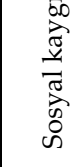 & 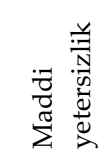 & 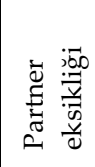 & 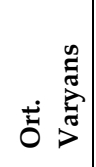 & 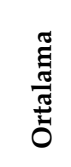 & $\begin{array}{l}\dot{\dot{n}} \\
\dot{\omega} \\
\dot{\vec{\omega}}\end{array}$ \\
\hline K8.Yüksekten korkmam & 0,816 & & & & & 0,711 & 2,63 & 1,391 \\
\hline K7.Yaralanmaktan korkmam & 0,755 & & & & & 0,645 & 2,72 & 1,367 \\
\hline K9.Liftlerden korkmam & 0,733 & & & & & 0,662 & 2,43 & 1,397 \\
\hline K6.Kış sporlarının çok tehlikeli olması & 0,718 & & & & & 0,613 & 2,84 & 1,365 \\
\hline $\begin{array}{l}\text { K17.Kış sporlarının yüksek düzeyde fiziksel } \\
\text { zorluk içermesi }\end{array}$ & 0,503 & & & & & 0,453 & 2,61 & 1,296 \\
\hline K26.Başka boş zaman faaliyetlerini tercih etmem & & 0,816 & & & & 0,675 & 3,10 & 1,284 \\
\hline $\begin{array}{l}\text { K27.Kayak tatilinin çok fazla planlama } \\
\text { gerektirmesi }\end{array}$ & & 0,630 & & & & 0,511 & 2,84 & 1,234 \\
\hline K28.Kış sporlarını yeterince çekici bulmamam & & 0,604 & & & & 0,445 & 2,79 & 1,367 \\
\hline $\begin{array}{l}\text { K23.Diğer boş zaman etkinliklerine fazlaca } \\
\text { bağlanmam }\end{array}$ & & 0,588 & & & & 0,413 & 2,84 & 1,319 \\
\hline K25.Pistlerin çok kalabalık olması & & 0,577 & & & & 0,402 & 2,84 & 1,299 \\
\hline K15.Kış sporlarına ayıracak zamanımın olmaması & & 0,521 & & & & 0,349 & 2,99 & 1,347 \\
\hline $\begin{array}{l}\text { K14.Arkadaşlarımın önünde küçük düşme } \\
\text { kaygısı }\end{array}$ & & & 0,774 & & & 0,657 & 2,14 & 1,349 \\
\hline K19.Öğrenme sürecinin küçük düşürücü olması & & & 0,733 & & & 0,633 & 2,35 & 1,341 \\
\hline K20.Çok stresli olacağını düşünmem & & & 0,716 & & & 0,583 & 2,37 & 1,311 \\
\hline K13.Arkadaşlarımın bu sporda çok iyi olmaları & & & 0,655 & & & 0,514 & 2,41 & 1,415 \\
\hline $\begin{array}{l}\text { K22. Kiş sporlarının elitist bir spor olduğunu } \\
\text { düşünmem }\end{array}$ & & & 0,495 & & & 0,382 & 2,58 & 1,284 \\
\hline K3.Yeterli paramın olmaması & & & & 0,834 & & 0,700 & 3,49 & 1,347 \\
\hline $\begin{array}{l}\text { K5.Kayak giysisi ve ekipmanlarının çok pahalı } \\
\text { olması }\end{array}$ & & & & 0,784 & & 0,626 & 3,54 & 1,305 \\
\hline K2. K1ş sporlarının yarattığ 1 pahalılık algısı & & & & 0,769 & & 0,605 & 3,45 & 1,312 \\
\hline K4.Arkadaşlarımın yeterli parasının olmaması & & & & 0,728 & & 0,597 & 3,29 & 1,353 \\
\hline $\begin{array}{l}\text { K10.Kayak merkezine birlikte gidecek kimse } \\
\text { bulamamam }\end{array}$ & & & & & 0,798 & 0,672 & 2,98 & 1,416 \\
\hline K11.Arkadaşlarımın zamanının olmaması & & & & & 0,790 & 0,711 & 2,94 & 1,334 \\
\hline K12.Arkadaşlarımın kış sporlarıyla ilgilenmemesi & & & & & 0,676 & 0,578 & 2,85 & 1,306 \\
\hline Özdeğerler & 2,888 & 2,819 & 2,795 & 2,588 & 2,048 & & & \\
\hline Açıklanan Varyans & 12,551 & 12,257 & 12,15 & 11,251 & 8,903 & & & \\
\hline Açıklanan Toplam Varyans & \multicolumn{5}{|c|}{57,112} & & & \\
\hline Ortalama & 2,65 & 2,90 & 2,37 & 3,44 & 2,92 & & & \\
\hline Std. Sapma & 1,045 & 0,872 & 0,987 & 1,054 & 1,100 & & & \\
\hline Güvenirlik & 0,825 & 0,748 & 0,788 & 0,801 & 0,748 & & & \\
\hline
\end{tabular}

Binişiklik durumunun ardından ortak varyans değerleri incelenmiştir. Bazı kaynaklarda 0,50 ve altında (Hair vd., 2010; Kalayc1, 2016), bazılarında ise 0,40 ve altında ortak varyans değerine sahip 
olan maddelerin ölçekten çıkarılabileceği ifade edilmektedir (Gorsuch, 1983; Floyd ve Widaman, 1995; Costello ve Osborne, 2005). Ancak Hair vd. (2010) ortak varyansı bu değerlerin altında kalan tüm maddelerin ölçekten çıkarılmasının doğru olmadığını, maddelerin faktör yükleri ve ölçek içindeki önemlerinin de değerlendirilmesi gerektiğini belirtmektedir. Eğer ilgili madde ölçek ve boyut için araştırmacı tarafından önemli görülen bir madde ise ve güçlü faktör yüküne sahipse, araştırmacı maddeyi ölçekte tutabilir. Yapılan ortak varyans incelemelerinde iki maddenin hem ortak varyanslarının 0,40'ın altında olduğu hem de faktör yapısını bozdukları görülmüştür. "Kayak merkezlerine toplu ulaşım eksikliği" maddesinin ortak varyansı 0,348, faktör yükü $0,475^{\prime}$ tir ve aynı boyuttaki diğer maddelerle uyumu bulunmamaktadır. Zira bu maddenin yer aldığı boyuttaki diğer maddeler partner eksikliğiyle ilgilidir. Dolayısıyla bu madde ölçekten çıkarılmışır. Diğer madde "yakınımdaki kayak merkezlerinin yeterince cazip olmaması" maddesidir. Bu maddenin ortak varyansı 0,368, faktör yükü 0,521'dir. Görüldüğü üzere, ortak varyansı düşük olsa da faktör yükü beklenen değerin üzerindedir $(0,521>0,40)$. Ancak ilgili maddenin, sosyal kaygı ile ilgili diğer maddelerle uyumlu olmadığı görülmüştür. Bu bağlamda, bu maddenin de ölçekten çıkarılmasına karar verilmiştir. Ortak varyansları 0,40'ın altında kalan iki madde daha vardır. Bunlar; "kış sporlarına ayıracak zamanımın olmaması" $(0,349)$ ve "kış sporlarının elitist bir spor olduğunu düşünmem" $(0,382)$ maddeleridir. Ancak bu maddelerinin hem faktör yükleri yüksektir (sırasıyla 0,$521 ; 0,495$ ) hem de ait oldukları boyutla uyumludurlar. Bu kapsamda, iki maddenin ölçekte tutulması uygun görülmüştür. Sonuç itibariyle AFA kapsamında altı madde ölçekten çıarılmış ve uygun bir faktör yapısı elde edilmiştir. AFA kapsaminda elde edilen nihai bulgular Tablo 1'de sunulmuştur.

En son yapılan AFA kapsamında elde edilen KMO örneklem yeterliliği $(0,861)$ ve Barlett Küresellik Testi değerleri $\left(x^{2}=3542,351 ; s d=253 ; p=0,000\right)$ de, verilerin AFA için uygun olduğuna işaret etmektedir. AFA, altı maddenin çıkarılmasıyla oluşan 23 maddeli ölçeğin beş boyutlu yapısı olduğunu ortaya koymuştur. Bu boyutlar, kapsadıkları maddeler esas alınarak; "korku ve tehlike", "cazip gelmeme", "sosyal kaygı", "maddi yetersizlik" ve "partner eksikliği" şeklinde isimlendirilmiştir. Bu beş boyut, toplam varyansın \%57'sini açılamaktadır. Bu değer, sosyal bilimlerde kabul edilebilir bir değerdir. Ayrıca güvenirlik katsayıları 0,748 ile 0,825 arasında değişen bu beş boyutun, yüksek düzeyde güvenilir faktörler olduğu görülmektedir.

Hangi kısıtların gençleri daha fazla etkilediğini sorgulayan Soru 2'ye cevap bulmak amacıyla maddelerin ve faktörlerin ortalama değerleri incelenmiştir. Bu kapsamda, katılımcıları kış turizmine katılma noktasında en fazla kısıtlayan faktör maddi yetersizlikler olduğu; ardından sırasıyla partner eksiliği, cazip gelmeme, korku ve tehlike ve sosyal kaygı gelmektedir. Maddelerin ortalama değerleri incelendiğinde, gençleri en fazla kısttlayan maddelerin "Kayak giysisi ve ekipmanlarının çok pahalı olması", "Yeterli paramın olmaması", "Kış sporlarının yarattığı pahalılık algısı", "Arkadaşlarımın yeterli parasının olmaması" olduğu anlaşılmaktadır. Gençleri en az kısıtlayan maddeler ise "Arkadaşlarımın önünde küçük düşme kaygısı", "Öğrenme sürecinin küçük düşürücü olması", "Çok stresli olacağını düşünmem", "Arkadaşlarımın bu sporda çok iyi olmaları" ve "Liftlerden korkmam" ş̧eklinde sıralanmaktadır.

\section{Demografik Farklılıklara İlişkin Bulgular}

Çalışmada Soru 3 kapsamında, kış sporlarına katılım kısıtı algılamaları açısından cinsiyet, gelir, bölge, rekreasyonel tercih ve Zigana'yı ziyaret değişkenlerinin kategorileri arasındaki farklılıklar incelenmiştir. Bu kapsamda, iki kategorili değişkenler olan gelir, cinsiyet ve Zigana ziyareti değişkenlerinin kategorileri arasındaki farklılıkları tespit etmek için bağımsız iki örneklem ttestinden; daha fazla kategorili değişkenler olan rekreasyonel tercih ve bölge değişkenlerinin kategorileri arasındaki farklılıkları incelemek içinse tek yönlü ANOVA'dan yararlanılmıştır. 
Analizler neticesinde, Zigana'yı ziyaret ve ikamet edilen bölge dişındaki değişkenlerde anlamlı değerler elde edilmiştir. Aşağıda anlamlı sonuçların elde edildiği cinsiyet, gelir ve rekreasyonel tercih değişkenlerine ilişkin bulgular sunulmuştur.

\section{Cinsiyet ve Gelire Göre Kısıt Algısı Farklılıkları}

Cinsiyet ve gelir değişkenleri kapsamında başvurulan T-testi bulguları, sadece anlamlı farklılıkların bulunduğu faktörler temel alınarak Tablo 2'de sunulmuştur. Çalışmada katılımcılara zorunlu giderler (kira vb.) dışında kalan harcanabilir gelirleri açık uçlu olarak sorulmuş, elde edilen verilere göre gelir durumu farklı şekillerde sınıflandırılmaya çalışılmıştır. Ancak diğer sınıflandırma türlerinde kategoriler arasında çok fazla örneklem farklılığı ortaya çıktığından, katılımcıların gelirlerinin ortalaması alınmış (641 TL) ve katılımcılar ortalamanın altında ve üstünde geliri olanlar şeklinde iki grupta değerlendirilmiştir. Gerçekleştirilen T-testi sonucunda sadece maddi yetersizlik boyutu açısından iki gelir grubu arasında anlamlı farklılık olduğu; F1 $(p=0,519>0,05), \quad F 2 \quad(p=0,216>0,05), \quad F 3 \quad(p=0,879>0,05) \quad$ ve $\quad$ F5 $\quad(p=0,687>0,05)$ faktörlerindeki ortalama farklılıklarının anlamlı olmadığı görülmüştür. Beklendiği üzere, maddi yetersizlik boyutundan ortalamanın altında harcanabilir geliri olan katılımcilar daha fazla etkilenmektedirler. Diğer bir ifadeyle, gelir durumu fark etmeksizin tüm katılımcılar diğer faktörler tarafından benzer şekilde kısıtlanırken; maddi yetersizlik faktörü ortalamanın altında geliri olanları anlamlı bir şekilde daha fazla kısıtlamaktadır.

Tablo 2. Cinsiyet ve Gelir Değişkenlerine İlişkin T-Testi Bulguları

\begin{tabular}{|l|l|l|l|l|l|c|}
\hline Faktörler & Değişken & Kategoriler & N & Ortalama & Std. Sap. & Anlamlılık \\
\hline \multirow{2}{*}{ F1. Korku ve tehlike } & \multirow{2}{*}{ Cinsiyet } & Kadın & 280 & 2,8257 & 0,99413 & \\
\cline { 3 - 6 } & & Erkek & 177 & 2,3424 & 1,05747 & 0,000 \\
\hline \multirow{2}{*}{ F4. Maddi yetersizlik } & \multirow{2}{*}{ Gelir } & 640 TL ve altı & 323 & 3,5116 & 1,05922 & \multirow{2}{*}{0,016} \\
\cline { 3 - 6 } & & 641 TL ve üstü & 134 & 3,2519 & 1,02024 & \\
\hline
\end{tabular}

Cinsiyet değişkeni açısından bakıldığında; sadece korku ve tehlike boyutunda anlamlı farklılıklar bulunmuştur. Kadınlar erkeklere oranla, kış sporlarının yarattığ tehlike ve korkudan daha fazla etkilenmektedir. Diğer bir ifadeyle, diğer faktörleri kadın-erkek fark etmeksizin tüm katılımcılar benzer şekilde algılarken; korku ve tehlike faktörünü kadınlar anlamlı bir şekilde daha fazla etkili bulmaktadirlar.

\section{Rekreasyonel Tercih Açısından Kısıt Algısı Farklılıkları}

Çalışmada katılımcılara boş zamanlarında en sık yaptığı şey açı uçlu olarak sorulmuş ve elde edilen yanıtlara göre katılımcılar rekreasyonel tercih sınıflandırmasına tabi tutulmuştur. $\mathrm{Bu}$ kapsamda, Stebbins'in (2017) rekreasyonel etkinlik sınıflandırmasından yararlanılmıştır. Stebbins (2017:16), boş zamanı kayıtsız boş zaman, ciddi boş zaman ve proje tabanlı boş zaman şeklinde üç başlık altında incelemektedir. Kayıtsız boş zaman, anında ve içsel faydalar sağlayan, etkinlikten keyif almak için özel bir çalışma gerektirmeyen ya da çok az gerektiren ve nispeten daha kısa süreli hoşnutluk sağlayan aktivitelere dahil olunarak geçirilen zaman dilimi olarak tanımlanmaktadır. Kayıtsız boş zaman açısından yazar sekiz kategori tanımlamaktadır: oyun, rahatlama, aktif eğlence, pasif eğlence, sosyal iletişim, duyusal dürtüler, kayıtsız gönüllülük, 
eğlenceli aerobik aktiviteler. Ciddi boş zaman ise kariyer elde etmek amacıyla oldukça önemli, ilginç ve tatmin edici olan, kendine özgü bilgi, beceri ve deneyim gerektiren amatör, hobi ya da gönüllü faaliyetlerdir. Stebbins (2017:17) ciddi boş zaman katılımcılarını hobiciler, amatörler ve gönüllüler şeklinde sinıflandırmaktadır. Yazar, proje tabanlı faaliyetlerde ise özel projeler ve mesleki projeler şeklinde iki alt grup belirlemiştir.

Bu çalışmada Stebbins'in yukarıda değinilen sınıflandırması esas alınmakla birlikte, etkinliklere katılımın aktif veya pasif olmasına göre eklemeler de yapılmıştır. Örneğin yazarın sinuflandırmasinda hem evde dinlenme, uzanma vb. tamamen pasif faaliyetler hem de gezinme, dolaşma vb. aktif faaliyetler kayıtsız boş zamandaki "rahatlama" kapsamında değerlendirilmektedir. Bu çalışmada aktif ve pasif rahatlama şeklinde iki alt sınıf tanımlanmıştır. Ayrıca yazarın tanımladığı etkinler arasında, günümüzün en önemli boş zaman değerlendirme etkinlikleri arasında olan sanal eğlenceler belirgin bir şekilde yer almamaktadır. Bu noktada, bilgisayar oyunları, sosyal medya vb. sanal içerikli etkinlikler için "sanal eğlence" ögesi dahil edilmiştir.

Bulgular Stebbins'in (2017) tanımladığı tüm aktivitelerin katılımcilar tarafından değerlendirilmediğini ve çoğunlukla kayıtsız boş zaman etkinliklerinin gerçekleştirildiğini göstermiştir. Kayıtsız boş zaman kapsamında "pasif eğlence", "aktif eğlence ve oyun", "sanal eğlence", "pasif rahatlama", "aktif rahatlama", " "sosyal iletişim"; ciddi boş zaman kapsamında ise sadece "spor" etkinliğinin değerlendirildiği görülmüştür. Bu kategoriler arasında kış turizmine katılım kısıtlarını algılama açısından farklılıklar olup olmadığını belirlemek amacıyla gerçekleştirilen Tek Yönlü ANOVA, sadece "korku ve tehlike" ile "partner eksikliği" faktörlerinde anlamlı farklılıklar olduğunu göstermiştir (Tablo 3). Cazip gelmeme ( $\mathrm{p}=0,514>0,05)$, maddi yetersizlik $(p=0,067>0,05)$ ve sosyal kayg1 $(p=0,729>0,05)$ boyutlarında ise anlaml farklılıklar gözlenmemiştir. Diğer bir ifadeyle, bu faktörler rekreasyonel etkinlik tercihi fark etmeksizin tüm katılımcılar tarafından benzer şekilde algılanmaktadır.

Tablo 3. Rekreasyonel Tercih Değişkeni Açısından ANOVA Bulguları

\begin{tabular}{|c|c|c|c|c|c|c|}
\hline Faktörler & Kategoriler & $\mathbf{N}$ & Ort. & Std. Sp. & $\mathbf{P}$ & Farklar \\
\hline \multirow{8}{*}{$\begin{array}{l}\text { F1. Korku ve } \\
\text { tehlike }\end{array}$} & A) Pasif eğlence & 154 & 2,6753 & 0,97151 & \multirow{8}{*}{0,020} & \multirow{8}{*}{$\mathrm{E}<\mathrm{D} ; \mathrm{E}<\mathrm{A}$} \\
\hline & B) Pasif rahatlama & 74 & 2,6892 & 1,03322 & & \\
\hline & C) Sanal eğlence & 68 & 2,6353 & 1,07395 & & \\
\hline & D) Aktif rahatlama & 63 & 2,9079 & 1,03477 & & \\
\hline & E) Spor & 48 & 2,1625 & 1,13262 & & \\
\hline & F) Sosyal iletişim & 31 & 2,6968 & 1,01833 & & \\
\hline & G) Aktif eğlence \& oyun & 15 & 2,4933 & 1,20681 & & \\
\hline & Toplam & 453 & 2,645 & 1,04547 & & \\
\hline \multirow{8}{*}{$\begin{array}{l}\text { F5. Partner } \\
\text { eksikliği }\end{array}$} & A) Pasif eğlence & 154 & 2,8006 & 1,12774 & \multirow{8}{*}{0,028} & \multirow{8}{*}{$\mathrm{E}<\mathrm{C} ; \mathrm{A}<\mathrm{C}$} \\
\hline & B) Pasif rahatlama & 74 & 2,8472 & 1,22408 & & \\
\hline & C) Sanal eğlence & 68 & 3,3138 & 0,86765 & & \\
\hline & D) Aktif rahatlama & 63 & 2,9583 & 1,03456 & & \\
\hline & E) Spor & 48 & 2,7225 & 1,03902 & & \\
\hline & F) Sosyal iletişim & 31 & 3,1397 & 1,10165 & & \\
\hline & G) Aktif eğlence \& oyun & 15 & 2,756 & 1,25022 & & \\
\hline & Toplam & 453 & 2,9206 & 1,09987 & & \\
\hline
\end{tabular}


Tablo 3 incelendiğinde; boş zamanlarında daha çok sportif etkinlikleri tercih edenlerin, pasif eğlence ve aktif rahatlama temelli aktiviteleri tercih edenlere göre "korku ve tehlike" boyutundan daha az etkilendikleri görülmektedir. Bu bağlamda, kış sporlarının yarattı̆̆1 korku ve tehlike unsurlarının, spor ağırlıklı rekreasyonel tercihi olanları, pasif eğlenceciler ve aktif rahatlayıcılara göre daha az kısıtladığı anlaşılmaktadır. Partner eksiliği faktörü açısından oluşan farklılıklara bakıldığında ise sanal eğlencecilerin, sporculara ve pasif eğlencecilere göre bu kısıtı daha önemli gördükleri anlaşılmaktadır.

\section{Kış Sporlarına Yönelik İlgi Düzeyine İlişkin Bulgular}

Çalışmada gençlerin kış sporlarına yönelik ilgi düzeyleri, tek maddeli bir ölçekle ölçülmüş ve Soru 4'e yanıt aranmıştır. Bulgular gençlerin kış turizmine yönelik ilgilerinin genel olarak düşük olduğunu göstermektedir $(\bar{x}=2,35)$. Bu noktada ilgi düzeyi üzerinde hangi faktörlerin etkisi olduğu sorusu (S5) akla gelmektedir. Bu soruya yanıt almak amacıyla başvurulan çoklu doğrusal regresyon analizinde, anlamlı korelasyon ve regresyon değerlerine ulaşılmıştır. Bu bağlamda, ilgi düzeyinin, korku ve tehlike $(r=-0,189 ; p=0,000)$, cazip gelmeme $(r=-0,208 ; p=0,000)$ ve partner eksikliği ( $r=-0,123 ; p=0,009)$ ile negatif yönlü anlamlı ilişkisi olduğu; sosyal kayg1 $(r=-0,066 ; p=$ $0,079)$ ve maddi yetersizlikle $(r=0,062 ; p=0,094)$ ilişkisinin ise anlamlı olmadığı görülmüştür. Ayrıca gerek anlamlı ilişkilerde gerekse anlamsız ilişkilerde Pearson korelasyon katsayılarının genel olarak düşük olduğu fark edilmektedir. Fakat korelasyon katsayıları ve bağımsız değişkenlerin bağımlı değişkeni açıklama yüzdesi düşük olsa da $\left(\mathrm{R}^{2}=0,071\right)$, ilgili modelin anlamlı olduğu ( $\mathrm{F}=6,849 ; \mathrm{P}=0,000)$ tespit edilmiştir (Tablo 4).

Tablo 4. Kısıtların İlgi Düzeyi Üzerindeki Etkisine İlişkin Regresyon Analizi Bulguları

\begin{tabular}{|c|c|c|c|c|c|}
\hline \multirow[b]{2}{*}{ Model } & \multicolumn{2}{|c|}{ Standardize olmayan katsayılar } & \multirow{2}{*}{\begin{tabular}{|c|} 
Standardize Katsayılar \\
Beta \\
\end{tabular}} & \multirow[b]{2}{*}{$\mathbf{t}$} & \multirow[b]{2}{*}{$\mathbf{p}$} \\
\hline & B & Std. Hata & & & \\
\hline Sabit & 3,030 & 0,275 & & 11,000 & 0,000 \\
\hline Korku ve Tehlike & $-0,175$ & 0,068 & $-0,145$ & $-2,571$ & $0,010^{*}$ \\
\hline Cazip Gelmeme & $-0,246$ & 0,081 & $-0,169$ & $-3,039$ & $0,003^{* *}$ \\
\hline Sosyal Kayg1 & 0,140 & 0,074 & 0,109 & 1,910 & 0,057 \\
\hline Maddi Yetersizlik & 0,110 & 0,058 & 0,091 & 1,897 & 0,059 \\
\hline Partner Eksikliği & $-0,096$ & 0,060 & $-0,083$ & $-1,584$ & 0,114 \\
\hline \multicolumn{6}{|c|}{ Bağımlı Değişken=İlgi Düzeyi } \\
\hline \multicolumn{6}{|c|}{$R^{2}=0,071 ;$ Düz. $R^{2}=0,061 ; F=6,849 ; P=0,000$} \\
\hline
\end{tabular}

*0,05 düzeyinde anlamlı.

**0,01 düzeyinde anlamlı

Tablo 4'te görüldügü üzere, sadece "korku ve tehlike" ile "cazip gelmeme" faktörlerinin ilgi düzeyi üzerindeki etkisi anlamlıdır. Bu iki faktör kış sporlarına ilgi düzeyini olumsuz etkilemektedir. Korku ve tehlike algısındaki bir birimlik artış, ilgi düzeyinde 0,175'lik bir azalışa neden olmaktadır. Cazip gelmeme algısındaki bir birimlik artış ise ilgi düzeyinde 0,246'llk bir azalışa sebebiyet vermektedir. Bu kapsamda, gençlerin ilgi düzeyinin düşük olması üzerinde en büyük etkiyi bu sporun onlara cazip gelmemesinin yarattığı, ardından korku ve tehlike algılamalarının geldiği ifade edilebilir. Sosyal kaygı, maddi yetersizlik ve partner eksikliği ise ilgi düzeyi üzerinde anlamlı etki yaratmamaktadır. Bu kapsamda, insanların arkadaşları önünde 
küçük düşme kaygısı yaşadıklarında, maddi kaynakları yetersiz olduğunda veya birlikte kayak yapacak kimse bulamadıklarında kış sporlarına katılım açısından kısıtlandıkları, ancak bu spora yönelik ilgilerinin anlamlı bir şekilde azalmadığı anlaşılmaktadır. Öte yandan, kış sporlarına katılmaktan korktuklarında, bu sporu tehlikeli bulduklarında veya cazip bulmadıklarında, katılım açısından kısıtlanmalarına ek olarak, ilgilerinin de azaldığ

\section{SONUÇ, TARTIŞMA ve ÖNERILLER}

Kış sporları, hem insanların spor yaparak sağlıklı kalmalarını sağlayan hem de yapıldığı bölgelere ekonomik getiri sağlayan bir spor çeşididir. Güncel istatistikler, 2018-2019 yılında ziyaretçi sayısında artış olduğunu gösterse de, son 15 yıldır kış sporlarına katılım hızının genel olarak yavaşladığını, özellikle gençlerin kış sporlarına yönlendirilmesi noktasında sorunlar olduğunu ortaya koymaktadır (Vanat, 2020). Bu noktada, insanların kış sporlarına katılım kısıtlarının incelenmesi önem kazanmaktadır. Mevcut çalışmada, Türkiye'de kış sporlarına ağırlıklı olarak katılan kesim olan gençlerin katılım kısıtları incelenmiştir. Bu bağlamda, Gümüşhane Üniversitesi öğrencileri üzerinde gerçekleştirilen çalışmada; gençler açısından hangi kısıtların öne çıktığı, hangi kısıtların hangi demografik özelliklere sahip olan gençleri daha fazla etkilediği, gençlerin kış sporlarına yönelik ilgi düzeylerinin ne durumda olduğu ve ilgi düzeyleri üzerinde hangi kısıtların etkili olduğu gibi sorulara yanıtlar aranmıştır.

AFA kapsamında elde edilen bulgular, kısıtlar ölçeğinin beş boyutlu yapısı olduğunu göstermektedir. Ortaya konan bu yeni faktör yapısı, Crawford vd., (1991) tarafından geliştirilen ve çoğu araştırmada kabul gören Hiyerarşik Boş Zaman Kısıtları Teorisiyle uyumlu değildir. Crawford vd.'nin (1991) teorisi boş zaman kısıtlarını kişisel, kişilerarası ve yapısal şeklinde kategorize ederken; mevcut çalışmada kısıtlar "korku ve tehlike", "cazip gelmeme", "sosyal kaygı", "maddi yetersizlik" ve "partner eksikliği" şeklinde sınıflandırılmıştır. Ancak bu bulgular, çalışmayla daha yakından ilgili olan kış sporları kısıtları araştırmalarıyla uyumludur. Örneğin Williams ve Fidgeon (2000) Kanada'da, Michailidis vd., (2006) Yunanistan'da yürüttükleri çalışmalarda kış sporları kısıtlarının "korku/tehlike", "maliyet kısıtları" ve "zorluk" şeklinde sınıflandırılabileceğini ortaya koymuşlardır. Alexandris vd., (2017) ise yine Yunan örneklem çerçevesinde, "bireysel/psikolojik", "partner eksikliği", "çevresel”, “zaman”, "maliyet" şeklinde sinıflandırmada bulunmuşlardır.

Bulgular, gençlerin en çok maddi yetersizlik temelli kısıtları öne çıkardığını göstermektedir. Özellikle kayak ekipmanları ve giysilerine ilişkin maliyet, katılımcıların büyük çoğunluğunu etkilemektedir. Ayrıca partner eksikliği ve kış sporlarının cazip gelememesi de önemli görülmekte; sosyal kaygı ve korku-tehlike algisı temelli kısıtlar ise nispeten daha az önemli görülmektedir. Bu bulguların literatürle büyük ölçüde uyumlu olduğu ifade edilebilir. Örneğin Priporas vd., (2012), Yunanistan'da gerçekleştirdikleri araştırmada kümeleme analizi neticesinde oluşan beş kümede de finansal kısıtların en önemli kısıtlar olduğunu ortaya koymuşlardır. Andronikidis vd.'nin (2007) yine Yunanistan'da yaptıkları araştırmada da yakın sonuçlara ulaşılmış; maddi yetersizlik temelli kısıtlar en önemli kısıtlar olarak görülmüştür. Maddeler özelinde bakıldığında ise her iki çalışma da mevcut çalışmayı destekler şekilde, en önemli kısıt maddesi kayak giysisi ve ekipmanlarının fiyatları olmuştur. Bulguların Yunanistan dışındaki kayak pazarı üzerine yürütülen çalışmalarla da uyumlu olduğu söylenebilir. Örneğin Williams ve Fidgeon (2000), Kanada'daki kış turizmi pazarında en önemli kısıtın ekipman maliyetleri olduğunu ortaya koymuştur. Ancak Williams ve Fidgeon'un (2000), ekipman maliyetinin ardından gelen en önemli kısıtın kış sporlarının içerdiği fiziksel zorluklar olduğu yönündeki tespiti, mevcut çalışmayla farklık göstermektedir. Bu çalışmada kış sporlarının zorluğu ve yarattı̆̆1 korku-tehlikeye ilişkin maddeler, diğerlerine oranla daha az kısıtlayıcı olarak 
görülmüştür. Bu kapsamda, Türk gençlerinin henüz bu sporu deneyimlememiş olsalar dahi, zorluk ve korku algılamalarının düşük olduğu görülmektedir. Fakat kadınları bu noktada ayrıca değerlendirmekte fayda vardır. Yapılan farklılık analizleri, kadınların kış sporlarına yönelik korku ve tehlike algılarının erkeklere göre, anlamlı bir şekilde daha fazla olduğunu göstermiştir. Literatürde yer alan diğer bazı çalışmalar da kadınların, özellikle kişisel nedenlerle, kış sporlarına katılma konusunda erkeklere oranla daha fazla kısıtlandıklarını göstermektedir (Williams ve Lattey, 1995; Hudson, 2000).

Bulgular, katılımcıların boş zaman alışkanlıklarının kısıt algılarını şekillendirdiğini göstermektedir. Yapılan farklılık analizlerine göre; boş zamanlarında daha çok spor temelli etkinler gerçekleştiren gençlerin pasif eğlence ve aktif rahatlama etkinlikleri gerçekleştirenlere göre kış sporlarına yönelik korku-tehlike algılarının daha düşük olduğunu göstermiştir. Bu noktada, spor temelli etkinliklere ve onların yarattığı tehlikelere zaten alışkın olanların, günlerini müzik dinleme, kitap okuma ve film izleme gibi pasif eğlence etkinlikleri veya gezinme, yürüyüş ve piknik gibi aktif rahatlama etkinlikleriyle geçirenlerden daha az korku-tehlike hissettikleri anlaşılmaktadır. Farklılık analizleriyle ayrıca sanal eğlencecilerin, partner eksikliği kısıtını sporcu ve pasif eğlencecilere göre daha fazla önemsedikleri görülmüştür. Bu kapsamda, günlerini bilgisayar veya telefon başında sosyal medya veya oyunlarla ilgilenerek tek başlarına geçirenlerin, özellikle grup halinde sportif etkinliklere katılanlara ve film-tv izleme gibi kısmen grupla yapılabilen etkinliklere katılanlara göre partner eksikliğini daha önemli buldukları anlaşılmaktadır.

Çalışmada ortaya konan önemli bulgulardan biri de gençlerin kış sporlarına yönelik ilgi düzeyleriyle ilgidir. Bulgular gençlerin kış sporlarına yönelik ilgi düzeylerinin zayıf olduğunu ve bu durum üzerinde sadece "korku ve tehlike" ile "cazip gelmeme" faktörlerinin etkisinin anlamlı olduğunu göstermektedir. Bu noktada, gençlerinin yeterli paralarının olmamasının, partner bulamamalarının ve sosyal olarak kaygılanmalarının (küçük düşme vb.) kış sporlarına yönelik ilgilerini anlamlı bir şekilde azaltmadığ 1 ; fakat korku ve tehlike hissettiklerinde ve bu spor türü onlara cazip gelmediğinde ilgilerinin anlamlı bir şekilde azaldığı anlaşılmaktadır. Bu durumda, korku-tehlike ve cazip gelmeme algılarının kış sporlarında sadece katılımı kısıtlamakla kalmadığı, aynı zamanda ilgisizlik yarattığı yorumunda bulunulabilir. Öyle ki, maddi yetersizlik en önemli görülen, ortalaması en yüksek kısıt olmasına rağmen, ilgi düzeyi üzerinde negatif etki yaratmamaktadır. Bu bulgunun literatürü destekler nitelikte olduğunu ifade etmek mümkündür. Priporas vd. (2015), Yunan kış turizmi pazarı üzerinde gerçekleştirdiği çalışmada, finansal olarak kısıtlananların tehlike algılarının "genel olarak kısıtlılar kümesine" ve "aile-arkadaş kısıtlıları" kümesine göre daha düşük olduğunu ortaya koymuşlardır. Benzer şekilde, Alexandris vd. (2007) yine Yunan örneklem üzerinde, insanların kış sporlarında üstesinden gelip gerçek kayakçılara dönüşmesi açısından en etkili değişkenin; korku, tehlike ve zorlukla ilişkili olan beceri geliştirme değişkeni olduğunu tespit etmiştir.

Literatürde yerli kış turizmi pazarının kış sporlarına katılım kısıtlarını inceleyen bir çalışmaya rastlanmasa da, kış turizmi alanında yapılan diğer bazı çalışmalardan kısıtlara ilişkin ipuçları elde edebilmek mümkündür. Örneğin Ayaz ve Apak'ın (2017), yerli kayak turistlerinin seyahat davranışlarını incelendikleri çalışmalarında, katılımcıların \%43'ünün kayak tatilinde bir günden daha az vakit geçirebildikleri ortaya konmuştur. Bu bulgunun, mevcut çalışmada ortaya konan, katılımcllarının \%84'ünün Zigana'ya kayak için henüz gidemediği/gitmediği yönündeki bulguyla benzerlik gösterdiği ifade edilebilir. İki çalışmada da, insanların çeşitli nedenlerle kış sporlarına katılamadıkları ya da destinasyonlarda çok az vakit geçirebildikleri tespit edilmiştir. Öte yandan, Evren ve Kozak (2019), Türkiye' deki beş kış turizmi destinasyonunun performansını kıyasladıkları çalışmalarında, ödenen para karşılığı alınan değer, bilet (skipass) fiyatı ve konaklama fiyatı gibi maliyet temelli özelliklerin, Türkiye kış turizmi pazarı açısından önemli 
olduğunu ortaya koymuşlardır. Bu çalışmada da, parayla ilgili kısıtların ortalamasının oldukça yüksek olduğu tespit edilmiştir. Benzer şekilde, Koşan (2013) da Palandöken'de beklenti-tatmin temelli yaptığı araştırmada, havayolu ulaşımı, mekanik tesisler gibi ana özelliklerin yanı sıra, uygun fiyatların da ziyaretçilerin önemli beklentileri arasında yer aldığını tespit etmiştir. Demiroğlu (2016) ise mevcut çalışmadaki değişkenlerden farklı bir konuya, iklim değişikliğine değinmiş ve iklim değişikliğinden kaynaklanan kar azlığı sorununun kış sporlarına katılımı azalttığını tespit etmiştir. Yazar ayrıca, pazarın önemli bir bölümünün (\%70) iklim değişikliği temelli sorunların farkında olduğunu ortaya koymuştur.

Çalışmada elde edilen bulgular kapsamında, araştırmacılara ve sektör profesyonellerine bazı önerilerde bulunulmaktadır. Bu çalışmada genel olarak üniversite gençliği ve özelde Gümüşhane Üniversite öğrencileri hedef alındığı için, gelecek çalışmalarda araştırmacılara genç nüfusun geri kalan kısmını oluşturan kişiler (üniversite öğrencisi olmayan gençler) ve diğer üniversitelerin öğrencileri üzerinde çalışmaları önerilmektedir. Böylece, mevcut çalışmanın bulgularıyla tartışılarak, genç nüfusa ilişkin daha iyi genellemelerde bulunulabilir.

Sektörel öneriler kapsamında ise maddi yetersizlik boyutunun ortalamasının yüksek çıkmasına bağlı olarak, öğrenci pazarı üzerinde farklı fiyatlama tekniklerinin geliştirilmesi önerilebilir. Özellikle kayak ekipmanı kiralarının en yüksek ortalamaya sahip madde olduğu düşünüldügünde, öğrencilere uygun fiyatlarla giysi ve ekipman sağlanması, onları pazarın bir parçası haline getirebilir. Öğrencilik hayatlarını tamamlayıp iş hayatına girdiklerinde de, bu pazarın bir parçası olarak kalacaklarından, bu öneri özellikle uzun vadede önemlidir. Öte yandan, korku-tehlike ve cazip gelmeme faktörlerinin gençlerin kış sporlarına yönelik ilgilerini zayıflattığı bulgusundan hareketle, destinasyon yöneticilerine kampüslerde gençlere kış sporlarını sevdirme etkinlikleri düzenlemeleri önerilebilir. Bu durum, Gümüşhane özelinde değerlendirildiğinde, gençlerin sadece \%14,9'unun Zigana'yı kış sporları için ziyaret ettiği ve ilgi düzeyinin çok düşük olduğu da hesaba katılırsa, Zigana destinasyonunun yöneticilerinin Gümüşhane Üniversitesi öğrencilerine bu sporu sevdirecek ve korkularını yenmelerini sağlayacak kampüs etkinlikleri yapmaları önerilebilir. Bu kapsamda, özellikle Zigana'da veya başka yerde kayak yapmış ve bu deneyiminden zevk almış öğrencilerden yararlanılabilir. Zira gençler, birbirlerinden büyük ölçüde etkilenmektedirler. Bu kapsamda, pazarlama 4.0 mantığ 1 çerçevesinde müşterilerin savunucular haline getirilmesi ve bu noktada özellikle sosyal medya araçlarından yararlanılması etkili olabilir. Bu teknik, partner eksikliği sorunu yaşayan sanal eğlenceciler, korku-tehlike algısı olan pasif eğlenceciler ve aktif rahatlamacılar üzerinde de etkili olabilir. Kadın katılımcıların korku-tehlike faktörü tarafından daha çok kısıtlanmış oldukları düşünüldügünde ise başvurulacak kampüs etkinliklerinde veya sosyal medya çalışmalarında, korkuyu aşma eksenli temalara vurgu yapılması etkili olabilir. Ayrıca tüm genç pazarı açısından bakıldığında, gençlerin korkularını aşmaları ve bu sporu daha cazip bulmaları için kayak derslerinde fiyat esnekliği sağlanabilir. Bu esneklik, her ne kadar ders fiyatları Türkiye Kayak Federasyonu tarafından belirlense de, özellikle toplu ders alımlarında etkili olabilir. Bu noktada, federasyonun da onayı alınarak gerekli çalışmalar yapılabilir.

Yukarıda ele alınan tüm sektörel önerilerle birlikte, kış turizmi ve kış sporları alanında gelişmiş ülkelerdeki uygulamaların takip edilmesi ve iyi örneklerin Türkiye'ye uyarlanması da tavsiye edilebilir. Bu sayede, özellikle kış sporlarına daha fazla kişinin katılması, diğer bir ifadeyle kış turizmi pazarının büyümesi için örnek uygulamalar keşfedilebilir. Bu kapsamda verilebilecek önemli örneklerden biri ABD'deki Ulusal Kayak Alanları Birliği'nin (NSAA) büyüme modelidir. NSAA, kış sporlarının gelişimi için en önemli konunun, yeni başlayan kayakçları sürekli kayakçılara "dönüştürmek" olduğunu belirtmektedir. Kurum, bir süredir bu konu üzerinde çalışmaktadır ve $\mathrm{ABD}^{\prime}$ deki çoğu kayak merkezinin destek verdiği çalışmalar sayesinde 2015 yılında \%15 olan “dönüştürme” oranının 2018' de \%19'a yükseldiğini açılamıştır. Kuruma göre, 
bu süreçte; modern öğrenme merkezleri, bilet-ders-ekipman fiyatlarında iyileştirmeler, yeni başlayan kayakçı ekipmanlarının geliştirilmesi ve işçi teşvikleri gibi çabalarla daha fazla yeni kayakçı kazanılmıştır. Ancak henüz istenen düzey yakalanamamıştır. Bu kapsamda kurum, "dönüştürme" çalışmalarına devam edileceğini belirtmektedir. NSAA, ayrıca "dönüştürme" sürecini süreklilik arz eden bir araştırmayla da takip etmektedir. Bu kapsamda, yeni başlayanlar uzun vadede gözlenmekte, belirli aralıklarla anket uygulanmaktadır. Bu sayede yeni başlayanların kış sporlarına yönelik eğilimleri gözlem altında tutulmaktadır (NSAA, 2020a, 2020b, 2020c). Türkiye'de de, destinasyonlar ve Türkiye Kayak Federasyonu işbirliğinde, NSAA veya benzer uygulamalara başvuran diğer ülkelerdeki kurumlar ve onların gelişim programları incelenip, henüz \%1 düzeyinde olan kış sporlarına katılım oranı yükseltilebilir.

\section{KAYNAKÇA}

Albayrak, A. (2013). Kış Turizmi Turistlerinin Seyahat Motivasyonları, 14. Ulusal Turizm Kongresi: Turizmde Yenilik, Erciyes Üniversitesi 05-08 Aralık 2013. Kayseri. ss. 144-164.

Alexandris, K. and Carrol, B. (1997). Demographic Differences in the Perception of Constraints on Recreational Sport Participation: Results from a Study in Greece, Leisure Studies, 16(2): 107-125.

Alexandris, K., Du, J., Funk, D. and Theodorakis, N.D. (2017). Leisure Constraints and the Psychological Continuum Model: A Study among Recreational Mountain Skiers, Leisure Studies, 36(5): 670-683.

Alexandris, K., Kouthouris, C., Funk, D. and Chatzigianni, E. (2008). Examining the Relationships Between Leisure Constraints, Involvement and Attitudinal Loyalty among Greek Recreational Skiers, European Sport Management Quarterly, 8(3): 247-264.

Andronikidis, A., Vassiliadis, C.A., Priporas, C. and Kamenidou, I. (2007). Examining Leisure Constraints for Ski Centre Visitors: Implications for Services Marketing, Journal of Hospitality $\mathcal{E}$ Leisure Marketing, 15(4): 69-86.

Ayaz, N. ve Apak, Ö. C. (2017). Kış Turizmine Katılan Yerli Ziyaretçilerin Seyahat Davranışları: Erciyes Kayak Merkezi Örneği, Erciyes Üniversitesi İktisadi ve İdari Bilimler Fakültesi Dergisi, 49: 2743.

Büyüköztürk, Ş., Çokluk, Ö. ve Köklü, N. (2012). Sosyal Bilimler için İstatistik. Ankara: Pegem Akademi.

Chick, G., Hsu, Y.C., Yeh, C.K., Hsieh, C.M., Ramer, S., Bae, S.Y., Xue, L. and Dong, E. (2018). Cultural Consonance Mediates the Effects of Leisure Constraints on Leisure Satisfaction: A Reconceptualization and Replication. Leisure Sciences, 1-20. https://www.tandfonline.com/doi/pdf/10.1080/01490400.2018.1506724?needAccess=true [Erişim Tarihi: 09.05.2020].

Cochran, W.G. (1977). Sampling Techniques. New York: John Wiley \& Sons.

Costello, A.B. and Osborne, J. (2005). Best Practices in Exploratory Factor Analysis: Four Recommendations for Getting the Most from Your Analysis, Practical Assessment, Research, and Evaluation, 10(7): 1-9.

Crawford, D.W. and Godbey, G. (1987). Reconceptualizing Barriers to Family Leisure. Leisure Sciences, 9: 119-127.

Crawford, D.W., Jackson, E.L. and Godbey, G. (1991). A Hierarchical Model of Leisure Constraints, Leisure Sciences, 13: 309-320. 
Demiroglu, O. C. (2016). Türkiye'deki Kış Sporları Turistlerinin İklim Değişikliği Algı ve Uyumları üzerine Ampirik bir Çalışma. I. Ulusal Alternatif Turizm Kongresi, Erzincan Üniversitesi 07-09 Nisan 2016. Erzincan. ss. 140-147.

Evren, S. ve Kozak, N. (2019). Kış Turizmi Destinasyonlarının Algılanan Performansı: Türkiye'deki Beş Destinasyonun Kıyaslaması, Anatolia: Turizm Araştırmaları Dergisi, 30(1): 45-56.

Floyd, F.J. and Widaman, K.F. (1995). Factor Analysis in the Development and Refinement of Clinical Assessment Instruments, Psychological Assessment, 7(3): 286-299.

Fredman, P. and Heberlein, T.A. (2005). Visits to the Swedish Mountains: Constraints and Motivations, Scandinavian Journal of Hospitality and Tourism, 5(3): 177-192.

Gilbert, D. and Hudson, S. (2000). Tourism Demand Constraints: A Skiing Participation, Annals of Tourism Research, 27(4): 906-925.

Gorsuch, R.L. (1983). Factor Analysis. Hillsdale, NJ: Erlbaum.

Gümüşhane Üniversitesi (2020). Yıllara Göre Öğrenci Sayıları. https://obs.gumushane.edu.tr/oibs/public_stats/index.aspx [Erişim Tarihi: 07.05.2020].

Gürbüz, B. ve Karaküçük, S. (2007). Boş Zaman Engelleri Ölçeği-28: Ölçek Geliştirme, Geçerlik ve Güvenirlik Çalışması, Gazi Beden Ĕ̆itimi ve Spor Bilimleri Dergisi, 12(1): 3-10.

Hair, J.F., Black, W.C., Babin, B.J. and Anderson, R.E. (2010). Multivariate Data Analysis: Global Perspective. Upper Saddle River, NJ: Pearson Education.

Hubbard, J. and Mannell, R.C. (2001). Testing Competing Models of the Leisure Constraint Negotiation Process in a Corporate Employee Recreation Setting, Leisure Sciences, 23: 145-163.

Hudson, S. (2003). Winter Sport Tourism. In S. Hudson (Editor), Sport and Adventure Tourism (pp. 89-124). New York: The Haworth Hospitality.

Hudson, S., Hinch, T., Walker, G. and Simpson, B. (2010). Constraints to Sport Tourism: A CrossCultural Analysis, Journal of Sport \& Tourism, 15(1): 71-88.

Hung, K. and Petrick, J.F. (2012). Testing the Effects of Congruity, Travel Constraints, and SelfEfficacy on Travel Intentions: An Alternative Decision-Making Model, Tourism Management, 33(4): 855-867.

Kalaycı, Ş. (2006). Faktör Analizi, (Editör) Kalaycı, Ş.: SPSS Uygulamalı Çok Değişkenli İstatistik Teknikleri içinde (ss. 321-334) Ankara: Asil Yayın Dağıtım.

Kayış, A. (2006). Güvenirlik Analizi. (Editör) Kalaycı, Ş.: SPSS Uygulamalı Çok Değişkenli İstatistik Teknikleri içinde (ss. 404-421) Ankara: Asil Yayın Dağıtım.

Kline, R.B. (2016). Principles and Practice of Structural Equation Modeling. London: The Guilford Press.

Koşan, A. (2013). Kış Sporları Turizmi - Kayak Turistlerinin Kış Turizm Merkezlerini Algı ve Değerlendirmelerine Ait Bir Araştırma (Palandöken'de Bir Uygulama), Atatürk Üniversitesi Sosyal Bilimler Enstitüsü Dergisi, 17: 293-324.

Lawshe, C.H. (1975). A Quantitative Approach to Content Validity 1, Personnel Psychology, 28(4): 563-575.

Michailidis, A., Samathrakis, V., Mamalis, S. and Theodosiou, G. (2006). Understanding Participation Constraints of Potential Skiers, Tourism Economics, 12(3): 421-435. 
NSAA (2020a). Model for Growth. http://www.nsaa.org/growing-the-sport/model-for-growth/ [Erişim Tarihi: 07.05.2020].

NSAA (2020b). NSAA Beginner Conversion Study. http://www.nsaa.org/growing-thesport/beginner-conversion-study/ [Erişim Tarihi: 07.05.2020].

NSAA (2020c). NSAA Conversion Cookbook. http://www.nsaa.org/growing-thesport/conversion-cookbook/ [Erişim Tarihi: 07.05.2020].

Nyaupane, G.P. and Andereck, K.L. (2008). Understanding Travel Constraints: Application and Extension of a Leisure Constraints Model, Journal of Travel Research, 46(4): 433-439.

Priporas, C.V., Vassiliadis, C.A., Bellou, V. and Andronikidis, A. (2015). Exploring the Constraint Profile of Winter Sports Resort Tourist Segments, Journal of Travel Research, 54(5): 659-671.

Sağlık, E. ve Kocaman, G. (2014). Kayak Merkezlerinde Turistlerin Hizmet Kalite Algısının Belirlenmesi: Palandöken Kayak Merkezinde Bir Uygulama, Atatürk İletişim Dergisi, 6: 67-88.

Scott, D. (2003). Constraints. In J.M. Jenkins and J.J. Pigram (Eds). Encyclopedia of Leisure and Outdoor Recreation (pp. 75-78). London: Routledge.

Stebbins, R.A. (2017). Leisure Activities in Context: A Micro-Macro/Agency-Structure Interpretation of Leisure. New Jersey: Transaction Publishers.

$\begin{array}{llll}\text { TUIK } & \text { (2020a). Gençlik } & \text { İstatistikleri }\end{array}$ https://biruni.tuik.gov.tr/yayin/views/visitorPages/index.zul [Erişim Tarihi: 07.05.2020].

TUIK (2020b). Yillara Göre İl Nüfuslar. http://www.tuik.gov.tr/UstMenu.do?metod=temelist [Erişim Tarihi: 07.05.2020].

Vanat, L. (2020). 2020 International Report on Snow and Mountain Tourism. https://www.vanat.ch/RM-world-report-2020.pdf. [Erişim Tarihi: 07.05.2020].

Vassiliadis, C.A., Bellou, V., Priporas, C.V. and Andronikidis, A. (2018). Exploring the Negotiation Thesis Application among Ski Resort Tourists: A Segmentation Approach, Journal of Hospitality \& Tourism Research, 42(5): 716-739.

Walker, G. and Virden, R. (2005). Constraints on Outdoor Recreation. In Jackson E.L. (Editor). Constraints to Leisure (pp. 201-219), Venture: State College, PA.

Williams, P. and Fidgeon, P.R. (2000). Addressing Participation Constraint: A Case Study of Potential Skiers, Tourism Management, 21(4): 379-393.

Williams, P.W. and Lattey, C. (1994). Skiing Constraints for Women, Journal of Travel Research, 32(2): 21-25.

YÖK (2020). Yükseköğretim Bilgi Sistemi: 2018-2019 Öğretim Y1lı Yükseköğretim İstatistikleri. https://istatistik.yok.gov.tr/ [Erişim Tarihi: 07.05.2020]. 